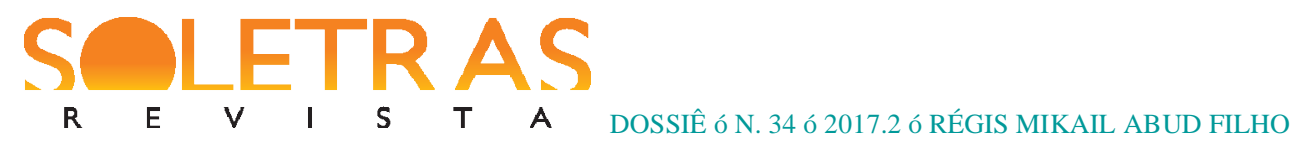

\title{
Léon Bloy contra seu tempo
}

Régis Mikail Abud Filho ${ }^{1}$

Resumo: Polêmico escritor francês do final do século XIX e crítico ferrenho de sua época, Léon Bloy é conhecido por sua pena feroz. O presente artigo traça um panorama da vida e obra deste autor, ainda insuficientemente estudado no Brasil. Três aspectos fundamentais de sua obra foram escolhidos, encarnados em sua fé católica única: a dor, o dinheiro e a arte. Sua obra é marcada por contradições como o dinheiro, que desempenha um papel redentor e maldito. Além da Bíblia, os escritos místicos e hagiográficos da Idade Média são fontes nas quais Bloy se inspira. A escatologia, o mistério da reversibilidade e o papel redentor da mulher fundamentam seus textos, explicados aqui por meio de exemplos. Sua perspectiva historiográfica baseia-se no ñsimbolismo universalò e no legado de autores como Barbey d'Aurevilly, Joseph de Maistre, Blanc-de-Saint-Bonnet e Thomas Carlyle. A literatura bloyana contraria as diretrizes artísticas de seu século, execra a cupidez burguesa, retratada como ridícula e satânica. Escrever não se apresenta como fim, mas como simples meio de se atingir o divino.

Palavras-chave: Léon Bloy. Literatura. Dor. Dinheiro. Arte.

\section{Introdução}

$\tilde{\mathrm{n} E}$ então, emlugar de perfume, haverá podridão, em lugar de cinto, uma corda, em lugar de cabelos encrespados, uma cabeça raspada, em lugar do largo manto, um cilício, uma cicatriz em lugar da beleza. Teus varões tombarão à espada, e teus bravos, na batalha. Suas portas gemerão e se lastimarão; e ela, despojada, sentar-se-por terra.ò

(Isaías3:24-26)

Há cem anos, precisamente a 3 de novembro de 1917, morria Léon Bloy em plena Primeira Guerra Mundial.Suas previsões sobre o fim dos tempos, desdobradas diante de seus olhos,foram registradas no volume póstumo Dans les ténèbres, de1918. Em 1846, ano de seu nascimento, Nossa Senhora da Salette, da qual foi profundamente devoto, proferiu palavras que assustaram os católicos modernos, ñcuja perfeita mediocridade talvez seja o sinal mais amedrontadorò $^{2}$ da segunda metade do século XIX (BLOY, 1999, p. 113).A mensagem comunicada por ñAquela que Choraò (BLOY, 2016) a dois pastorzinhos pobres e humildes,na

\footnotetext{
${ }^{1}$ Mestre em Literatura Geral e Comparada pela Universidade Livre de Berlim. Doutor em Literatura Francesa pela Université Paris-Sorbonne. E-mail: regismikail@gmail.com

${ }^{2}$ ñNos catholiques modernes dont la médiocrité parfaite est peut-être le signe le plus effrayant, pensent presque tous à des moyens humainsò.
}

SOLETRAS ï Revista do Programa de Pós-Graduação em Letras e Linguística ï PPLIN

Faculdade de Formação de Professores da UERJ

Número 34 (jul.-dez. 2017) - ISSN: 2316-8838

DOI: 
linguagem rude de seu dialeto alpino, alertava contra os vícios da humanidade pregando penitência e humildade.Convém lembrar que boa parte do culto mariano daquele século preferia alinhar-se à brandura das aparições de Nossa Senhora de Lourdes e da Rue du Bac, para citar apenas duas das mais conhecidas. Já a Virgem aos prantos prometia adventos magníficos a quem seguisse suas advertências e previa cataclismos horríveis a quem não a escutasse. ñÉ tarde ' escrevia o desolado Bloy pouco antes de falecer ' mesmo para o arrependimento. Só resta aceitar humildemente o extremo sofrimento, a perfeita ignomínia, a morte sem glóriaò(BLOY 1918, pp. 179-180). ${ }^{3}$

Mas quem foi Léon Bloy? Um ñempreendedor de demoliçõesò(BLOY, 1884), um dos maiores detratores do longo século XIX, esse ñséculo de carniçasò(BLOY, 2015)? Panfletário polêmico, empalador ${ }^{4}$ detestado por muitos ou revelador aceito por poucos? Preferiu-se por muito tempo ignorar esse escritor violento e temerário que, deve-se reconhecer, cometeu algumas injustiças ao julgar alguns de seus contemporâneos. Dentre suas diversas diatribes literárias, uma das mais conhecidas é a volta contra J.K. Huysmans, que pôs termo à breve e intensa amizade de ambos através de reproches ferrenhos ao autor de En route (1895) e Sainte Lydwine de Schiedam (1901). É curioso notar como os elogios precedentes de Bloy transfiguravam-se em exprobrações exatamente contrárias ao que havia dito. Acusava-se Bloy de egocentrismo maníaco. Se ele falava de si e os personagens remetiam a si próprio, é imperativo separar Bloy de toda a corrente autofictiva que começava a assolar sua época e que se prolonga até a atualidade.

Bloy foi um católico fervoroso, ñde uma estranha espécieò (BLOY, 2002, p. 82) ${ }^{5}$, como ele mesmo admitia. Fato é que combateu os ideais burgueses empunhando sua pena, a mesquinhez desses ñporcos que querem morrer de velhiceò (BLOY, 2007, p. 503) ${ }^{6}$, assim como nunca hesitou em vituperar o materialismo abjeto de seu século, palavra recorrente em sua escrita. Quaisquer que sejam os pareceres a seu respeito, há algo que não pode ser contestado: uma férobusta, hiperbólica como a de Jóe que pode parecer estranha em uma primeira leitura.

\footnotetext{
${ }^{3} \tilde{n}$ ll est trop tard même pour le repentir. Tout ce qu'on peut, c'est d'accepter humblement la souffrance extrême, l'ignominie parfaite, la mort sans gloire.ò(Esta e as traduções seguintes são minhas, salvo indicação).

${ }^{4}$ Trata-se de títulos de obras de Bloy, exceto ñempreendedor de demoliçõesò, epíteto cunhado por Barbey d'Aurevilly a respeito de Bloy e que servirá de título a Propos d'un entrepreneur de démolitions (1884).

${ }^{5}$ ñCatholiques [sic] moi-même, quoique d'une étrange espèce, je n'ai pas à recommencer l'écî urante besogne des anti-cléricaux, en accusant mes frères de scélératesse. Plût à Dieu qu'il n'y eût que cela !»

${ }^{6}$ BLOY, Léon. Journal Inédit III (1903-1907). Lausanne : Lô̂Age dâHomme, 2007.
} 
Tarefa árdua, embora necessária, relembrá-lo fora da França, onde vem progressivamente ganhando importância, já que raríssimas são as traduções de sua obra em português. ${ }^{7}$ Longe de almejar à exaustividade ' seria por acaso possível esgotar sua noção de Absoluto? ' ,propomos traçar aqui uma breve apresentação deste autor.Seus textos fazem-se mais ouvidos, seja pelo puro apreço literário que lhe poderiam conferir leitores ávidos por uma estética verbal no mínimo riquíssima;seja pela expressão simples e violenta de sua crença, capaz de comover tanto o mais convicto dos ateus quanto o mais simples dos cristãos. A literatura de Bloy vem aos poucos ganhando espaço na comunidade católica ${ }^{8}$, bem como nos meios literários, em boa parte devido à consistente fortuna crítica de seus estudiosos, como Pierre Glaudes, autor de Lôn uvre romanesque de Léon Bloy (GLAUDES, 2006). A atualidade ainda não deu ouvidos o suficiente a esse escritor, de quem não se pode separar a perspectiva cristã escatológica peculiar que procuraremos percorrer a seguir.

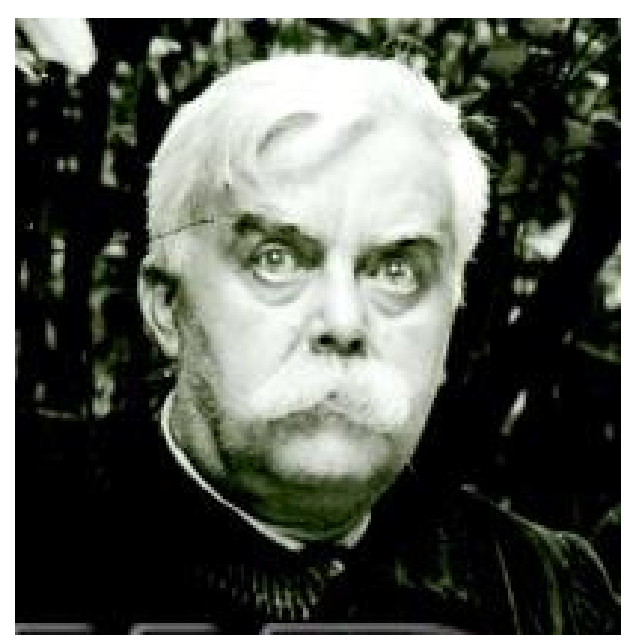

Fig. 1: Léon Bloy (1846-1917)

\section{Escatologia(s) e mistério}

ñVeio a mim a ideia de um livro infinitamente bizarro. Trata-se simplesmente de fazer sobressair do fato de La Salette toda uma concepção nova da Beleza católica e toda

\footnotetext{
${ }^{7}$ Podemos citar a tradução de trechos da obra de Bloy feitas por Octávio de Faria (Léon Bloy. Record Editora, Rio de Janeiro, 1968) e a recente tradução de Roberto Malet de Celle qui pleure (Aquela que chora. E outros textos sobre Nossa Senhora da Salette, Ecclesiae, 2016).

${ }^{8}$ Em homilia na Capela Sistina, o Papa Francisco citou Bloy: ñQuand on ne confesse pas Jésus Christ, me vient la phrase de Léon Bloy: óCelui qui ne prie pas le Seigneur, prie le diableô Quand on ne confesse pas Jésus Christ, on confesse la mondanité du diable, la mondanité du démon.ò Vide: <https://w2.vatican.va/content/francesco/fr/homilies/2013/documents/papafrancesco_20130314_omeliacardinali.html>. Acesso em: 20 jul. 2017.

${ }^{9}<$ https://commons.wikimedia.org/wiki/File:L\%C3\%A9on_Bloy_Dornac.jpg>. Acesso em: 20 jul. 2017.
} 
uma exposiçãoinesperada do destino humano emrelação à Revelação. ${ }^{10}$

(BLOY, in BOLLÉRY,1947, p. 447) $)^{11}$

Parece imperar um consenso tácito quanto a seu nome: não é apenas difícil, mas, sobretudo, delicado falar de Bloy. Será devido às críticas desse ñesfolador de burguesesò̀DE GOURMONT, 2007, p. 183) ${ }^{12}$ que nem os mais inflexíveis communards, os apoiadores da Comuna de Paris, ousaram fazer?Ou porque a imprensa de seu tempo, comandada pela mesma burguesia, segundo ele aviltada em seus ideais, impediram-no de conquistar seu espaço no século dos bien-pensants e do positivismo triunfante que perduram até hoje? Convém lembrar que Bloy foi associado por muito tempo ao estigma de um suposto antissemitismo, proposição absurda se compreendermos minimamente Le Salut par les juifs (1892), texto que suscitou viva polêmica. Ali, Bloy louva o povo judeu em oposição às ideias antissemitas de Drumont ao afirmar que o cristianismo não deveria se opor à religião judaica, mas honrá-la, já que o próprio Jesus e a Virgem Maria foram judeus. ${ }^{13} \mathrm{O}$ conservadorismo político-religioso de Bloy, bastante específico dentro do contexto francês,é uma forte característica que causaria espanto aos leitores atuais, conservadores e/ou atrelados ao neoliberalismo (se esses apenas o lessem...).É igualmente considerado radical demais aos católicos confortáveis do século XIX e do nosso,manifestamente preocupados em seguir uma tradição mais social do que propriamente espiritual.

Ao longo da segunda metade do século XIX, observa-se um topos da representação da fisiologia digestiva, sobretudo em personagens masculinos ${ }^{14}$. Antes de se chegar ao final do processo de digestão (que exerce um certo fascínio sobre Bloy, como veremos a seguir),a primeira etapa foi amplamente retratada nas narrativas literárias daquele século, de Balzac a Zola, de Sue a Huysmans: a boca; boca que come, que pronuncia, que insulta e que louva.Órgão responsável pela fala e pela vituperação na obra de Bloy, a boca é também o

\footnotetext{
${ }^{11}$ ñL'idée m'est venue d'un livre infiniment bizarre. Il s'agit simplement de faire jaillir du fait de La Salette toute une conception nouvelle de la Beauté catholique et toute une exposition inattendue de la destinée humaine par rapport à la Révélation.ò(BLOY, Léon, citado por BOLLÉRY, Joseph. Léon Bloy. Origines, jeunesse formation: 1846-1882. Paris: Albin Michel. 1947, p. 447).

12 O termo é de Remy de Gourmont em seu retrato literário de Bloy.

${ }^{13}$ Além da polêmica causada pela publicação de Le Salut par les Juifs, os desentendimentos com Louis Veuillot, diretor ultramontanista do jornal católico L'Univers, para o qual Bloy contribuiu por brevíssimo período (de 1873 a 1874), devem ser considerados. Outra diatribe digna de nota ocorreu também no meio jornalístico: Bloy desentendeu-se gravemente com a redação do Chat Noir em 1884.

${ }^{14}$ Vide PRZYBOS, Julia. Les Aventures du corps masculin. Paris: José Corti, 2012.
} 
órgão mais expressivo de sua condição de pobreza: a fome. Por exemplo, a personagem Clotilde, de La Femme pauvre, reflete a respeito da associação que os católicos ñde bemò fazem entre sua religião e os hábitos alimentares: ñ[...] a profunda liturgia dos comerciantes ortodoxos, a qual consiste em tirar o brinde do bolo no Dia de Reis, em comer bacalhau na Sexta-Feira Santa, panquecas durante a Festa de São João, carne suína no Natal [...] ò̀ ${ }^{15}$ O destino final deste percurso digestivo nos é conhecido e Bloy não se cala a seu respeito; o termo cloaque é frequentemente empregado por ele para se referir às abjeções dos burgueses e dos falsos católicos. Fortemente influenciado pela cultura latina, ele herda a verve satírica de um Juvenal e cria neologismos a partir de termos latinos. ${ }^{16}$ Para Bloy, eschatologie coincide frequentemente com scatologie, conforme observa Richard Griffiths (1988, p. 241-250); uma quase homofonia em francês que em língua portuguesa se realiza no mesmo significante e

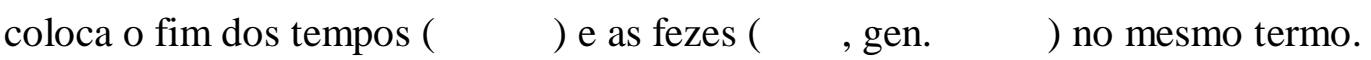

Este grande corpo social, no sentido mais grosseiro e desprovido de espiritualidade a burguesia ' deglute o materialismo, o progressismo, o cientificismo, a cupidez e a avareza. Um corpo que Bloy fustigou com suas duras impressões em forma de ficção, ensaio, aforismos e volumosos diários. Nem a filosofia é poupada de seu julgamento feroz: para ele, ela ñalvez não seja uma preocupação maldita, mas é, certamente, o que há de mais inútil no mundoò(BLOY, 1919, p. 362). ${ }^{17}$ Qual crítica aplicar, assim, a esse crítico que não só desprezava as ñbaixezasò do romance naturalista de Zola (Je m'accuse, 1899), mas, sobretudo,de uma boa parte dos romances de conversão de escritores como François Coppée e Paul Bourget, detratados em Les Dernières Colonnes de l'Église (1903)?

Em A falência da crítica (1973), Leila Perrone-Moisés demonstra a respeito de Lautréamont, autor, aliás, do qual Bloy foi um dos primeiros entusiastas, que as correntes críticas fenecem impotentes perante seus Cantos de Maldoror (1869). ${ }^{18}$ Da mesma maneira, a respeito da literatura de Bloy, nenhuma crítica parece bastar totalmente para sua

\footnotetext{
${ }^{15} \tilde{n}[. .$.$] la profonde liturgie des détaillants orthodoxes, laquelle consiste à tirer les Rois, à manger de la merluche$ le Vendredi Saint, des crêpes à la Saint-Jean, de la cochonnaille à Noël [...]ò. La Femme pauvre. Paris: Éd. Crès, 1924, p. 33. A expressão original empregada por Bloy é ñirer les Roisò (grifo do autor). Trata-se de uma celebração durante a festa da Epifania que consiste em esconder um brinde dentro de um bolo, a chamada fava (ñ̂èveò), geralmente em forma de moeda. Aquele cuja fatia contém o brinde é proclamado ñei do diaò e lhe é augurada boa sorte.

${ }^{16}$ Vide: GUYOT, Gaëlle. Latin et latinité dans l' î uvre de Léon Bloy. Paris: Honoré Champion, 2003.

${ }^{17} \tilde{n}$ La philosophie nôst peut-être pas une occupation maudite, mais elle est certainement ce quôl y a de plus inutile au mondeò

${ }^{18}$ Vide: PERRONE-MOISÉS, Leila. A Falência da crítica Ï Um caso limite: Lautréamont. São Paulo: Perspectiva, 1973.
} 
compreensão, nem mesmo a teológica. A literatura de Bloy, por mais complexa que pareça, é na verdade bastante simples, conforme as palavras de Monsenhor Baron a respeito do escritor a quem deve sua conversão: ñela parte de Deus e vai até Deusò. ${ }^{19}$ Seria, portanto, redutor limitar o pensamento de Bloy a uma mera teologia, ou pior, tentar encaixá-lo nos preceitos teológicos. Cabe aceitar o Mistério, contentar-se em exprimi-lo e observá-lo em sua beleza, ora evidente, ora latente, $\tilde{n}[. .$.$] simplesmente constatar o Mistério, a PRESENÇA do Mistério,$ para escândalo dos imbecis ou dos teólogos pedantes que afirmam que tudo já está esclarecidoò(BLOY, 1906, p. 159). ${ }^{20}$

As fontes de Bloy sorvem, em boa parte, os livros dos profetas do Antigo Testamento, dos quais herda as imprecações, as condenações e certas figuras de linguagem. Recusava a classificação de escritor profissional, afirmando que sua arte se limita a um pis-allerï um mal menor $^{21} \ddot{i}$,mero instrumento que Deus lhe deu para exprimir sua fé. Esta é igualmente marcada pelos primeiros santos e mártires do cristianismo, pela potência do Império Bizantino registrada em L'Épopée byzantine et Gustave Schlumberger (1906) e pela mística medieval da devotio moderna.

\section{Do Revelador do Globo aos últimos textos: panorama da obra bloyana}

Sua primeira publicação, um volume tardio e curioso, anteverá todos os temas posteriormente fundamentais em sua obra: Le Révélateur du Globe (1884), de cunho ensaístico, historiográfico e hagiográfico, foi publicado quando o autor tinha 37 anos.Nesta obra de exórdio,uma postulação pela santidade de Cristóvão Colombo, encontram-se temas como a Dor, o Dinheiro, a Pobreza e principalmente o propósito católico que Bloy via no navegador christophoros: o de levar o Verbo divino aos povos que o ignoravam,missão malfadada por culpa do ouro cobiçado pela Coroa espanhola. Fé e Dinheiro: estes mistérios tanto o obcecaram em vida que Bloy concebeu uma verdadeira mística do metal,ao mesmo tempo maldito e redentor.

19 Vide: documentário Léon Bloy, le Pèlerin de l'Absolu, de 1970. Disponível em: <https://youtu.be/LeotBROo6vk>. Acesso em: 3 abr. 2016.

${ }^{20}$ ñLes très-rares chrétiens qui font encore usage de leur raison peuvent remarquer qu'il ne s'agit pas, ici ou là, de métaphore, non plus que d'affirmation rigoureuse dans le sens de la doctrine révélée, mais simplement de constater le Mystère, la présence du Mystère, au scandale des imbéciles ou des théologiens pédants qui affirment que tout es t éclairci.ò

${ }^{21}$ Vide: GLAUDES, Pierre. Le tourment de l'irrévocable. (Lecture du Désespéré de Léon Bloy), p. 34-51, Bulletin de la Société des Études bloyennes, nº 3-4, novembre 1988 janvier 1989, p. 39. 
Barbey d'Aurevilly compôs o prefácio à primeira edição do Révélateur du globe. A esse amigo pessoal e padrinho literário atribui-se boa parte da expressão da fé de Bloy, que lhe havia dedicado um artigo,ñLa Méduse Astrucò (1875). Foi Barbey quem o introduziu ao pensamento de Antoine Blanc-de-Saint-Bonnet.O autor legitimista, ultramontano e contrarrevolucionário do ensaio De la Douleur, de 1849, expõe sobre o papel redentor da dor na religião cristã e da reversibilidade dos males:

Este dogma, sobre o qual repousam a força daqueles que vivem e a esperança daqueles que morrem, este dogma que liga o Céu à terra, e a terra com os lugares definitivos da provação, repousa ele próprio sobre a liberdade. Então esses três homens, o homem triunfante, o homem militante e o homem sofrente, formam apenas um único ser, de quem um pé já está posto no Céu. É assim que, à luz do infinito, todos os homens voltam a manifestar os membros uns dos outros. Os méritos de cada um se espalham sobre todos, neste misterioso corpo, pelo canal da reversibilidade, verdadeiro reestabelecimento da circulação do sangue da humanidade. (BLANC-DESAINT-BONNET, 2008, p. 140) ${ }^{22}$

Em Le Sang du pauvre (1909), Bloy ilustra a ideia de reversibilidade através da imagem cruel do pobre como expiador dos males dos ricos:

Sim, sem dúvida, esta certeza evangélica é revigoranteàqueles que sofrem neste mundo. Mas quando, pensando na reversibilidade das dores, lembra-se, por exemplo, que é necessário que uma criança pequena seja torturada pela fome em um quarto gelado para que uma cristã exultante não se prive das delícias de uma refeição delicada diante de um bom fogo; oh! então como é longa a espera! ecomocomprendo a justiça dos desesperados ${ }^{23}$ (BLOY, 2009, p.20).

O rico cumpre, paradoxalmente, um papel necessário neste sistema sobrenatural e divino da redenção dos males.Mas se apenas o rico, lamentava Bloy, se conformasse em ser o carrasco e não quisesse passar por católico.A falsa piedade e o falso dolorismo lhe são odiosos, de modo que atémesmo o paganismoparecepreferível:

Seu primeiro dever [dos ricos] seria evidentemente esmagar os pobres e o dos pobres seria de lhes matar por sua vez, quando apresentasse a ocasião.

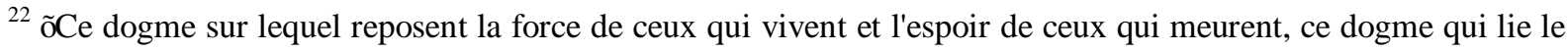
Ciel à la terre, et la terre, avec les lieux définitifs de l'épreuve, repose lui-même sur la liberté. Alors ces trois hommes, l'homme triomphant, l'homme militant et l'homme souffrant, ne forment qu'un seul être dont un pied s'est déjà posé dans le Ciel. C'est ainsi qu'à la lumière de l'infini, tous les hommes reparaissent les membres les uns des autres. Les mérites de chacun se répandent sur tous, dans ce mystérieux corps, par le canal de la réversibilité, véritable rétablissement de la circulation du sang de l'humanité.ò

${ }^{23}$ ñOui, sans doute, cette certitude évangélique est rafraîchissante pour ceux qui souffrent en ce monde. Mais lorsque, songeant à la réversibilité des douleurs, on se rappelle, par exemple, qu'il est nécessaire qu'un petit enfant soit torturé par la faim, dans une chambre glacée, pour qu'unechrétienne ravissante ne soit pas privée du délice d'un repas exquis devant un bon feu; oh ! alors, que c'est long d'attendre! et que je comprends la justice des désespérés!ò
} 


\section{SOLETRAS}

Mas eles querem ser católicos assim mesmo e católicos assim! Eles alegam esconder seus ídolos até dentro das Chagas adoráveis!...(BLOY, 2009, p. 22) ${ }^{24}$

A Dor estaria presente na vida e na obra de Bloy. O apadrinhamento de Barbey e os primeiros escritos no Chat Noir não bastariam para seu reconhecimento. Invendável, como indica o título de um dos diários, Bloy jamais conseguiria viver de literatura. Nada resta senão vociferar por escrito e mendigar, atividade da qual não se envergonhava, conforme observa-se em sua correspondência com Huysmans e Villiers de lđ̂sle-Adam, a quem costumava pedir dinheiro por escrito, com sua bela caligrafia. Em Exégèse des lieux communs (1902), Bloy esmiúça e subverte os clichês e os ditados populares com amarga ironia afirmando: ñTodo o mundo sabe que sou um mendigo e abusa dissoò(BLOY, 1902, p. 132). ${ }^{25}$ Ele acreditava que já que seu gênio não era reconhecido, lhe devessem dar ao menos de comer.

Antes do Révélateur du Globe, Bloy já havia tentado publicar em 1875 La Chevalière de la Mort, texto sobre outro personagem histórico, Maria Antonieta. Ali expôs sua visão sobre a Queda, a redenção pelos inocentes e a reversibilidade dos males. A rainha e seu filho, Luís XVII (Le Fils de Louis XVI,de 1910), são quase comparados a mártires, sem, no entanto, o serem propriamente, devido a seu papel sacrificial contra uma revolução humana, como vítimas necessárias ao preço de uma exigência divina.A Revolução francesa e suas mazelas, segundo Bloy, consistem numa redenção pelo mal, ideia que retoma os preceitos de Joseph de Maistre $^{26}$. Na concepção bloyana da História, que deve muito ao historiador inglês Thomas Carlyle, todo evento está inscrito na Providência divina, um ñsimbolismo universalò que explica o real através da configuração divina: ñA História é como um imenso texto litúrgico onde os iotas e os pontos valem tanto quanto versículos ou capítulos inteiros [...] Ò (BLOY, 1930, pp.14-15). ${ }^{27}$ Napoleão Bonaparte, por exemplo, figura misteriosa que conecta o Paracleto a Lúcifer, encarna esta ideia na qual está presente o conceito bloyano central de Absoluto, delineado em Lô̂̀me de Napoléon (1912). Grafado em letra maiúscula, marcado pelo mistério divino e pela sacralização do poder, o papel do carrasco é necessário, por mais opressor que seja. Ademais há de se considerara convicção de que a França, Galia poenitens

\footnotetext{
${ }^{24}$ ñAh ! si les riches modernes étaient des païens authentiques, des idolâtres déclarés ! il n'y aurait rien à dire. Leur premier devoir serait évidemment d'écraser les faibles et celui des faibles serait de les crever à leur tour, quand l'occasion s'en présenterait. Mais ils veulent être catholiques tout de même et catholiques comme ça! Ils prétendent cacher leurs idoles jusque dans les Plaies adorables !é ò

${ }_{25}$ ñTout le monde sait que je suis un mendiant et on en abuse.ò

${ }^{26}$ Vide: IX conversa de Les Nuits de Saint-Pétersbourg. (DE MAISTRE, Joseph. í uvres, suivies d'un Dictionnaire Joseph de Maistre, edição estabelecida por Pierre Glaudes. Paris : Robert Laffont, 2007, p. 708).

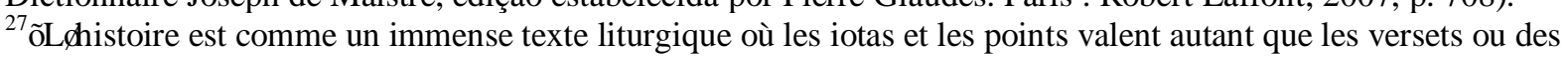
chapitres entiers [é ].ò
}

SOLETRAS ï Revista do Programa de Pós-Graduação em Letras e Linguística ï PPLIN

Faculdade de Formação de Professores da UERJ

Número 34 (jul.-dez. 2017) - ISSN: 2316-8838

DOI: 
et devota, é a pátria eleita do Cristo para a salvação, donde as constantes derrisões com ironia hiperbólica à burguesia, ao laicismo e aos bem-pensantes. Sua verve panfletária abunda em mordacidade, perfeitamente alinhada à sua visão do catolicismo, a exemplo do Pal (A Palanca), periódico que durou quatro números (o quinto não chegou a ser publicado, por motivos de baixas vendas e pelo espanto causado nas polêmicas incitadas ${ }^{28}$ ).

A pátria de Joana dôArc, santa ñmpossível de ser compreendida sem o sobrenaturalò, numa apropriação (muitíssimo) diferente de sua imagem usada por campanhas da atual extrema-direita francesa, é a nação santa por predestinação;a França é comparada a uma prostituta incorrigivelmente amada por Deus que, aflita por enormes penas, é contudo tratada amorosamente por Ele. Em Jeanne dôArc et lôAllemagne (1915), escrito durante a Primeira Guerra, Bloy traça um paralelo entre a virgem de Orléans como representante da vontade divina, da verdade católica e do destino desejado à nação durante a Guerra dos Cem Anos e a Alemanha dos séculos XIX-XX,tratada como potência satânica impulsionada por Lúcifer e seu protestantismo, verdadeira expressão do mal. Esses temas são igualmente abordados na coletânea de contos Sueur de Sang (1893), inspirados em sua vivência durante a Guerra Franco-Prussiana.

Em Celle qui pleure (1908), Vie de Mélanie écrite par elle-même (1912) e Le Symbolisme de l'Apparition (1925, póstumo), o apologista católico expõe a verdade testemunhada pelos pastores da Salette. Ao descrever hagiograficamente no prefácio o papel da pastora eleita, Bloy se põe a transcrever sua vida, de maneira similar. Qualquer preocupação em compor um texto literário vendável e com a glória da autoria é aqui absolutamente secundária. Seu objetivo se resume à grande tarefa de difundir a mensagem da Virgem. Em sua verdade simples e sua expressão vulgar, no sentido mais puro do termo, Vie de Mélanie é retransmitida tal qual, nas mesmas palavras de uma menina pobre, de alma profundamente simples e predestinada a trazer revelações.Fica evidente neste texto a verdade bloyana segundo a qual todo católico que não vê no rosto de Cristo um pobre, não é digno de ser considerado como tal.

Da ficção bloyana, a ironia e o questionamento dos modelos romanescos decadentistas e naturalistas ficaram registrados em Histoires désobligeantes (1894), coletânea de contos

\footnotetext{
${ }^{28}$ Ali, Bloy atacou personalidades do meio literário, como Victor Hugo e burgueses influentes como a família Hugues. Quando escrevia no Chat Noir, Bloy criticou violentamente o ñSârò Joséphin Péladan por conta de um desentendimento quando da morte de Barbey. Péladan chegou a processá-lo judicialmente. Sem, no entanto, ter se apresentado à corte no dia do julgamento, Bloy acabou sendo liberado.
} 
cujo título carrega em si o teor alegadamente desagradável, o humor negro e absurdo das palavras de seus personagens. As disputas e a dolorosa experiência espiritual de Bloy, descritas em ricas imagens mordazes foram retratadas no roman à clefsque é Le Désespéré (1887) e em La Femme pauvre (1897). Neste último, o autor recusa o título de romance para o ñepisódio contemporâneoò em que retrata temas como o papel de Eva e a Queda, a Redenção e violenta vinda do Espírito Santo em meio a estruturas que evocam o romance realista (como o balzaquiano).Um exemplo é a cena de abertura, decorrida entre mãe, padrasto e filha em uma casa operária,pobre e banal. Cabe ressalvar que os Chapuis (a mãe e o padrasto de Clotilde), indicam que nem todos os pobres são retratados como louváveis na ficção bloyana; no caso, esses são carrascos marcados pela cupidez desenfreada e pela falsa piedade.

O modelo do romance realista será intermitentemente subvertido no desenrolar da narrativa, cujo título inicialmente concebido havia sido La Prostituée, embora a heroína Clotilde não chegue a se prostituir. Se Bloy recorre ao modelo literário realista, é com o intuito de questioná-lo e estabelecer as relações, frequentemente paradoxais entre o profano e o sagrado, questões essas em boa parte ignoradas por seus contemporâneos, que as julgavam incompreensíveis. Há uma hesitação evidente em aproximar tais textos do gênero romanesco. Se é visível uma inovação artística, esta é mera decorrência da expressão da fé pela arte e não da busca de glória. Se abundam imagens sugestivas, metáforas e comparações curiosas (às quais não seria impertinente atribuir uma certa influência de $\grave{A}$ rebours, romance que havia elogiado antes de romper definitivamente com Huysmans), tais figuras de estilo servem para exprimir a fé ou condenar sua ausência. Assim,em Le Désespéré ${ }^{29}$, a tolice se manifesta em seus dizeres grandiosos como ñuma espécie de monstro na história do espírito humano, e que eu não posso comparar de maneira melhor senão a uma vegetação sifilítica sobre um admirável semblanteò(BLOY, Léon, 2009, p.18). ${ }^{30}$

\section{Hipérboles de fé, oxímoros do Verbo: A Mística e o Metal}

O oxímoro é caro a Bloy, a absolutização de seus ideais é escrita em letra maiúscula, à maneira de Baudelaire. Para Bloy, a Arte consiste na busca do Absoluto, e não em um fim por si só: ñPara dizer algo de valioso, bem como para dar a impressão do Belo, é indispensável

\footnotetext{
${ }^{29}$ O caráter violento de Le Désespéré e o temor de eventuais processos judiciais por parte do editor, que em nota declara não necessariamente compartilhar das ideias do autor, atrasaram a publicação do romance em um ano.

${ }^{30} \tilde{n}[. .$.$] une espèce de monstre dans l'histoire de l'esprit humain, et que je ne puis mieux comparer qu'à une$ végétation syphilitique à une admirable face.ò
} 
parecer exagerar, isto é, levar seu olhar além do objeto e, então, é a própria exatidão sem nenhum exagero, o que se pode verificar nos profetas, que foram todos acusados de exagerarò (BLOY, 2009, p.8). ${ }^{31}$

Os recursos de linguagem empregados, muito mais do que meras figuras de estilo literário, distantes daquilo que atribuía a Huysmans como ño prurido da palavra raraò(BLOY, 1903, p. 64) ${ }^{32}$, compõem seu Absoluto.A prostituta está mais próxima da santidade do que a burguesa honesta, como representado em Le Désespéré na figura dolorosa, no cruento sacrifício autoinfligido de Véronique, que raspou os cabelos e teve seus dentes arrancados um por um.

Tudo remete ao Dinheiro. A vida de Bloy foi marcada por duros contratempos causados pela penúria, causa da morte de seus dois filhos. O metal avilta o homem, mas desempenha função misteriosa e fundamental, sem o qual não há redenção: ñEle é execrável e adorável, símbolo flagrante e brilhante do Cristo Salvador, in quo omnia constatò (BLOY, 2009, p. 23) ${ }^{33}$. Vivendo a pobreza de um santo e vituperando com a veemência de um profeta, Bloy lê avidamente o legado dos místicos, então traduzidas do latim por seu amigo, o escritor católico Ernest Hello, como os relatos de Ângela de Foligno e os textos de Suso e Ruysbroeck. A Bíblia é o texto por excelência, a simplicidade dos escritos hagiográficos e místicos da Idade Média representam toda a simplicidade divina de uma época idealizada pela fé e pela devoção ${ }^{34}$. O princípio do dolorismo bloyano, alinhado àquele da Idade Média, repousa principalmente sobre a expressão da mística feminina, cujas vidas e visões, a exemplo de Catherine Emmerich, representam um verdadeiro estandarte da expiação dos males de seu século, bem como Ângela de Foligno, Catherine de Seine e Maria de Agreda em suas respectivas épocas. Trata-se de uma interpretaçãoque escritores como Bloy e Huysmans conferem àdevotio moderna,inserindo-a no contexto da expiação vitimal de males, própria do século XIX (BERG, 2008, p. 336).

\footnotetext{
${ }^{31}$ ñPour dire quelque chose de valable, aussi bien que pour donner l'impression du Beau, il est indispensable de paraître exagérer, c'est-à-dire de porter son regard au-delà de l'objet et, alors, c'est l'exactitude même sans aucune exagération, ce qu'on peut vérifier dans les prophètes, qui furent tous accusés d'exagérer.ò (BLOY, Léon. Le Pèlerin de l'Absolu, 11 de novembro de 1912. í uvres. Paris: Mercure de France, 1964-1975, pp.293-294.

${ }^{32}$ ñLe prurit du «mot rare », de « lấpithète rare » dont lôuteur dồ Rebours était déjà dévoré et qui le faisait se gratter partout [é ]ò

33 ñllestexécrable et adorable, symbole flagrant et ruisselant du Christ Sauveur, in quo omniaconstat.ò

${ }^{34}$ Em La Femme pauvre, por exemplo, constatou-se por ora 44 citações veterotestamentárias, 34 neotestamentárias, 13 referências litúrgicas e hagiográficas e 12 referências literárias.
} 
A ideia de que a prostituta está mais próxima da santidade do que a mulher honesta dialoga não só com a vida de certas santas e beatas, arrependidas de sua vida mundana, como é o caso de Ângela de Foligno e Margarida de Cortone, mas também com os fundamentos do papel do pobre na mística medieval, observados por Michel de Certeau:

[é ] [a pobreza] vê-se conceder uma função de contestação em uma sociedade onde a riqueza e a cultura deixam de ser cristãs. $O$ face-a-face muda. Ele não confronta mais dois tipos de conhecimento religioso ou duas categorias eclesiásticas, mas dois grupos sociais: o sábio torna-se rico e o ñibertinoò, o ignorante se identifica ao pobre e ao cristão(DE CERTEAU, 1982, p. 326). ${ }^{35}$

Esse aspecto da mística incorpora-se inclusive nas figuras reais de Mélanie e Maximin, pastores analfabetos, de pouca inteligência e simples; naquilo que de Certeau define como ñsimples particular, aquele que não tem a patente oficial do saber teológico e da função sagrada (DE CERTEAU, in PARISSE, 2006, pp. 25-26) ò $^{36}$; da mesma maneira que Bloy refere-se à Mélanie ñmersa em uma ignorância luminosaò(BLOY, 1912, p.11) ${ }^{37}$. A pobreza é também traço fundamental do protagonista Caïn Marchenoir, presente nos dois romances, e nas heroínas femininas: a prostituta Véronique Cheminot, sua amada, e Clotilde, mulher de origem pobre a quem a descoberta da fé dá rumo ao Absoluto. Viúva e sem dinheiro após perder o filho e o marido, Clotilde se aproxima de uma santidade mística do abandono, marcado por traços do cristianismo oriental, nas belas páginas finais de La Femme pauvre: ñTudo que acontece é adorávelò (BLOY, 1924, p.385) ${ }^{38}$. A mística do abandono a Deus e do desprovimento total se une assim às possibilidades do encadeamento de eventos do romance, às narrativas encaixadas. $\mathrm{O}$ avatar de Eva, da mulher arrependida, termina no eterno vagar da mulher cujo pecado fora redimido pela Virgem Maria, sob a forma de errante:

Coberta somente pelo capuz de um grande casaco negro que vai até o chão, e seus invisíveis pés nus em sandálias, sustentada há dez anos por uma energia

\footnotetext{
35 "[la pauvreté] se voit allouer une fonction de contestation dans une société où la richesse et la culture cessent d'être chrétiennes. Le face-à-face change. Il ne confronte plus deux types de connaissance religieuse ou deux catégories ecclésiales, mais deux groupes sociaux : le savant devient le riche et le 'libertin' ; l'ignorant s'identifie au pauvre et au croyant."

${ }^{36} \tilde{n}$ ñé ] simple particulier, celui qui n'a pas la patente officielle du savoir théologique et de la fonction sacréeò

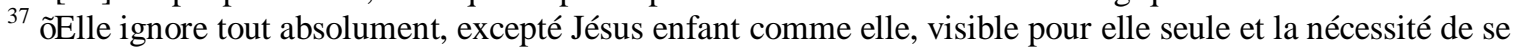
configurer à lui par la souffrance. Elle est immergée dans une ignorance lumineuse."

${ }^{38}$ ño Tout ce qui arrive est adorable, dit-elle ordinairement, de lâiir extatique dâine créature mille fois comblée qui ne trouverait que cette formule pour tous les mouvements de son cî ur ou de sa pensée, fût-ce à lôsccasion dône peste universelle, fût-ce au moment dô̂tre dévorée par des animaux féroces.ò
} 
muito mais que humana, não há frio nem tempestade que seja capaz de lhe meter medo. Seu domicílio é o da chuva que cai (BLOY, 1924, p.385). ${ }^{39}$

Cabe ressaltar que personagens como Caïn Marchenoir, presente tanto em Le Désespéré quanto em La Femme Pauvre,e Léopold, marido de Clotilde, retomam certos aspectos do próprio autor. A aventura de Marchenoir com Véronique em Le Désespéré remete diretamente aos anos em que Bloy viveu ao lado de Anne-Marie Roulé, prostituta do Quartier Latin com quem compartilhou uma intensa e delirante experiência mística. Ele descreveu-a em uma carta como ñuma menina ignorante que foi certamente tudo que se pode imaginar de mais sublime, a quem eu devo tudo o que valho intelectualmente e que eu prodigiosamente encolhi para fazê-la entrar em meu livroò(BLOY, in BOLLERY, 1947, p. 298). ${ }^{40}$. As consequências foram a loucura da prostituta arrependida, internada em um hospital psiquiátrico após ter confiado um segredo místico que assombraria Bloy por toda a vida.

A mulher bloyana, avatar de Eva arrependida na salvação trazida pela Virgem Maria retoma duas manifestações do feminino bastante presentes no século XIX: por um lado a da mulher como objeto de interesse psiquiátrico; por outro, a da mulher como figura mariana expiadora, que remete a Eva e seu culto oriental, a exemplo de Clotilde. Diversas demonstrações de fé, como cultos e peregrinações voltadas às santas e a Maria eclodiram, sobretudo, a partir da segunda metade daquele século. O corpo feminino na expressão artística e social da época torna-se o corpo eleito para a Dor ' psíquica ou espiritual ' , donde o papel importante desempenhado pela santidade feminina do cristianismo. Tal santidade, no entanto,não se completa no caso das heroínas, tampouco se apresenta de maneira não problemática.

A mística, da qual se deve dissociar a santidade, era já na época de Bloy vagamente compreendida e efusivamente exaltada por muitos artistas da segunda metade do século XIX.Termo erroneamente empregado e explorado das mais diversas maneiras pelos escritores, a mística foi em grande parte um termo ñprostituídoò, palavra empregada por Bloya respeito da palavra ñmartírioò.

Já falei dessa raiva de prostituir as palavras. Precisamente, a do martírio me faz pensar nas infames tolices da hora atual. A tal ponto se está na carne e a

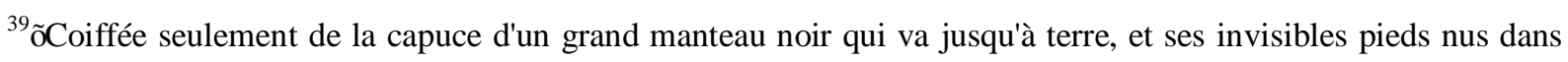
des sandales, soutenue depuis dix ans par une énergie beaucoup plus qu'humaine, il n'y a ni froid ni tempête qui soit capable de lui faire peur. Son domicile est celui de la pluie qui tombe.ò

${ }^{40} \tilde{n}[. .$.$] une ignorante fille qui fut certainement tout ce qui peut être imaginé de plus sublime, à qui je dois tout ce$ que je vaux intellectuellement et que j'ai prodigieusement rapetissé pour la faire entrer dans mon livre.ò
} 
abolição dos sentidos das palavras é tão requerida que basta falar de sofrimento para despertar a ideia de martírio. Há crianças mártires, mulheres mártires, há até animais mártires. O sentido da palavra está absolutamente destruído (BLOY, 2003, p. 127). ${ }^{41}$

Um dos motivos era a própria inovação verbal que os escritos místicos despertavam nos autores confessionais e não confessionais do século XIX, ávidos por novas manifestações e possibilidades estéticas. A dita ñaventura místicaò das santas extáticas não consiste em uma aventura de si,embora seja frequentemente expressa em uma linguagem idiossincrática e estonteante que não raramente parece costear o erotismo; ela compreende sobretudo o abandono de si a fim de encontrar Deus.Logo, dista amplamente da empresa puramente autocentrada num desvario espiritual e autofictiva na escrita.

A pobreza material contrastada com os tesouros espirituais instaura-se como elemento fundamental, não só para a santidade e a mística, mas como condição para ser católico. O dinheiro que corrompe é causa principal das desgraças para Bloy, e justamente por isso cumpre seu papel redentor:

[...] este terrível Dinheiro, mais formidável que a Prece e mais conquistador que o Incêndio, já que foi preciso tão pouco para comprar a Segunda Pessoa divina e que será preciso menos ainda, talvez, para surpreender o grande Amor, quando ele descer sobre a terra!(BLOY, 1924, p.130) ${ }^{42}$

Clotilde, a ñmulher pobreò, é apenas materialmente pobre, pois será levada para a vida mística no caminho da pobreza. Deste papel paradoxal do dinheiro, ño eucarístico dinheiro que se bebe e que se come(BLOY, 2009, p. 24) ${ }^{43}$ ò, ressaltamos a seguir três pontos cunhados sobre a fé cristã de Bloy abordados em nossas próximas considerações: a Dor, a Arte e a Pobreza, elementos fundamentais da criação bloyana que, no caminho ingrato da arte perante Deus, reformula a Gênese, preferindo contemplar a Criação em letra maiúscula à simples criação literária: ñSomente é possível ser si mesmo ao voltar ao estado que precede a Quedaò

\footnotetext{
${ }^{41}$ ñ'ai déjà dit cette rage de prostituer les mots. Précisément, celui de martyre me fait penser aux infâmes sottises de l'heure présente. On est tellement dans la viande et l'abolition du sens des mots est si demandée qu'il suffit de parler de souffrance pour éveiller l'idée de martyre. Il y a des enfants martyrs, des femmes martyrs, il y a même des animaux martyrs. Le sens du mot est absolument détruit.òAssim, em La Femme pauvre, a terrível e falsa beata mère Chapuis é comparada à Cymodicée do romance Les Martyrs, de Chateaubriand. Na escrita romanesca de Bloy, os personagens ímpios, materialistas, cúpidos, entre outros, são frequentemente associados a personagens de romances pelos quais Bloy tinha pouco apreço.

${ }^{42} \tilde{n}[\ldots]$ cet effrayant Argent, plus formidable que la Prière et plus conquérant que l'Incendie, puisqu'il en a fallu si peu pour acheter la Seconde Personne divine et qu'il en faudra moins encore, peut-être, pour surprendre le grand Amour, quand il descendra sur la terre! ò

${ }^{43} \tilde{\text { ñé }] ~ l ' e u c h a r i s t i q u e ~ a r g e n t ~ q u ' o n ~ b o i t ~ e t ~ q u ' o n ~ m a n g e . o ̀ ~}$
} 
(BLOY, 1999, p.183). ${ }^{44}$

\section{Da Dor divina}

Convém evocar as deliciosas páginas de L'Ami des bêtes, originalmente publicada na primeira edição das Histoires désobligeantes, e posteriormente retomada em La Femme pauvre, sob a forma de digressão do personagem Marchenoir. O personagem relata, quando de uma visita ao Jardin des Plantes, o exemplum do pobre vegetariano, corroído pela culpa de um crime, pateticamente submisso e ridicularizado por outros fieis em uma estalagem em La Salette. Não cederemos aqui à tentação de resumir essa pequena joia literária, tampouco a deixamos transcrita. Contentemo-nos em reduzir a ideia central desta história de expiação, Queda, amor pelos animais e reversibilidade dos males. As feras ' no caso os tigres presos enjaulados ' desempenham um papel redentor sofrendo para nós e por nós ' ñcum ipso et per ipso $^{45}$ ' , cumprindo um papel vitimal através do sofrimento misterioso:

Quando vemos um animal sofrer, a piedade que sentimos só é viva porque ela toca em nos o pressentimento da Libertação. Nós acreditamos sentir, como vocês estavam dizendo neste instante, que esta criatura sofre sem ter merecido, sem compensação de tipo algum, visto que ela não pode esperar outro bem além da vida presente e que então é uma injustiça terrível. É portanto preciso que ela sofra por nós, os Imortais, se nós não quisermos que Deus seja absurdo.(BLOY, 1924, p. 85)

A visita ao zoológico desencadeia um discurso a respeito do mistério dos animais segundo Marchenoir, instituindo-se uma verdadeira subversão ao procedimento analítico exercido pelos naturalistas. Do Éden ao zoológico, o estado do homem antes da Queda é transformado em taxonomia e divertimento. No Jardin des Plantes, as feras de olhar desolado, como o pobre felino que outrora vivia em ñsua bela floresta na Índia, há apenas alguns meses, e agora, morre de frio e de tristeza sob os olhos do populachoò (BLOY, 1924, p.

\footnotetext{
${ }^{44}$ ñOn ne peut être soi qu'en remontant à l'état qui précède la Chute.ò

${ }^{45}$ Vide: FONTENAY, Élisabeth. Le Silence des bêtes. Paris : Fayard, 1998, p. 354. A expressão citada retoma o latim de missa quanto à relação a Cristo do homem pecador e salvo.

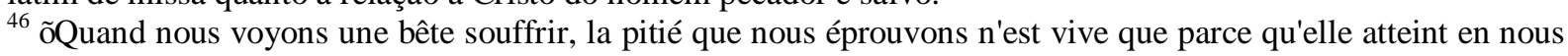
le pressentiment de la Délivrance. Nous croyons sentir, comme vous le disiez à l'instant, que cette créature souffre sans l'avoir mérité, sans compensation d'aucune sorte, puisqu'elle ne peut espérer d'autre bien que la vie présente et qu'alors c'est une effroyable injustice. Il faut donc bien qu'elle souffre pour nous, les Immortels, si nous ne voulons pas que Dieu soit absurde.ò
} 
$81)^{47}$,representam uma oposição ao estado anterior à Queda, numa antítese do Paraíso, pois cumprem seu sacrifício no século.

Em Bloy, até os pecados e os vícios tornam-se absolutos, como as prosopopeias da Covardia, da Avareza, da Imbecilidade e da Crueldade (BLOY, 1886, p. 119) ${ }^{48}$, como podemos observar em Le Désespéré. Neste romance, o testemunho das angústias de Marchenoir, ñrelinchando de vontade de sofrerò o fazem rolarñcomo um bisãoò̀BLOY, 1886, p. $349,118,119)^{49}$, atormentado por este pensamento incofortável.As tentações seguem umas às outras e se constituem como animais tradicionalmente associados ao diabo, como escorpiões e quimeras. Em seguida é descrito, não sem certos laivos decadentistas, o vício da Embriaguez como uma ñEsfingeò e o pecado da Preguiça, que ñ [é ] sai da vagina como um verme, enrola-se com indiferença viscosa a todos os pilastros da velha cidade humanaò (BLOY, 1886, p. 119) ${ }^{50}$. Mesmo uma virtude, axial do Cristianismo ' oAmor ' , é representada de maneira inquietante na angústia de Marchenoir, repugnante como o animal invertebrado e sem forma que é o caramujo preso à sua concha:

Mas o amor espuma à simples palavra de compartilhar e o ciúmes é sua casa. É um caramujo sem pátria, que se delicia, sem convidados, em sua espiral tenebrosa. Há olhos na extremidade de seus cornos e, por mais levemente que os toquemos de leve, ele volta para dentro de si mesmo para se devorar. Ao mesmo tempo, ele é ubiquitário, quanto ao tempo e quanto ao espaço,

\footnotetext{
${ }^{47}$ ñll était dans sa belle forêt de l'Inde, il y a quelques mois à peine, et maintenant, il meurt de froid et de chagrin sous les yeux de la canaille.ò

${ }^{48} \tilde{n}$ LôOrgueil et sa bâtarde, la Colère, se laissent brouter par leurs flatteurs; la pacifique Envie lèche lôntérieur des pieds fromageux de lôAvarice, qui trouve cela très bon et qui lui donne des bénédictions hypothéquées avec la manière de sấn servir ; lấvrognerie est un Sphynx toujours pénétré, qui sâen console en allant se soûler avec ses í dipes; la Luxure, au ventre de miel et aux entrailles dôairain, danse, la tête en bas, devant les Hérodes, pour quôon lui serve les décapités dont elle a besoin, et la Paresse, enfin, qui lui sort du vagin comme une filandre, sânroule avec une indifférence visqueuse à tous les pilastres de la vieille cité humaine.ò

${ }^{49}$ ñMais la seule pensée dôın tel risque le détermina, ð étant de ces fiers chevaux, qui sấventrent sur les baïonnettes, en hennissant de la volupté de souffrir ! e «Aussitôt que cette fange lâeut touché, le misérable amoureux sôy roula, comme un bison. »

50 «la Luxure, au ventre de miel et aux entrailles dâairain, danse, la tête en bas, devant les Hérodes, pour quâon lui serve les décapités dont elle a besoin, et la Paresse, enfin, qui lui sort du vagin comme une filandre, sâenroule avec une indifférence visqueuse à tous les pilastres de la vieille cité humaine. »Optamos por traduzir r̃filandreò, como ñvermeò. $\mathrm{O}$ termo em francês, polissêmico, parece designar de fato no contexto da passagem um tipo específico de verminídeo. Como afirmará mais tarde em seu diário, o demônio, para Bloy, não se resume a um monstrengo que poria medo em crianças, mas ele estaria na própria realidade, nos olhos do quitandeiro da esquina que se recusa a dar de comer para um miserável: ñÀ nous deux [Bloy e Jeanne, sua esposa], l'idée d'un article où j'établirais la jocrisserie des occultes qui ont besoin des rites et de grimoires pour sentir la présence du démon et qui ne voient pas le satanisme à crever les yeux de leur épicier, par exemple.ò (BLOY, Léon. Journal inédit, 4 vols., texto estabelecido por Marianne Malicet et Joseph Royer, sob direção de Michel Malicet, Pierre Glaudes et Joseph Royer. Lausanne ; [Paris]: l'Âge d'homme, 2013, vol. I, p. 1307).
} 


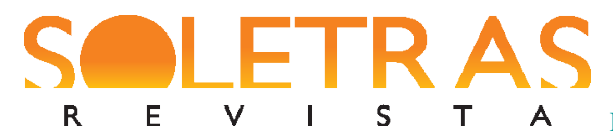

DOSSIÊ ï N. 34 ï 2017.2 ï RÉGIS MIKAIL ABUD FILHO

como o verdadeiro Deus do qual ele é a mais assustadora desfiguração (BLOY, 1886, p.119)

Se o amor e a redenção divina são manifestações de Dor e de Deus, não há para Bloy nada de mais radicalmente afastado do que as motivações que levavam milhares de peregrinos a Lourdes buscandocura para suas doenças. De maneira mais ou menos próxima daquela de Huysmans, autor de Les Foules de Lourdes (1906), Bloy não crê que haja salvação sem sacrifício, o que o leva a buscar o sofrimento com avidez. Se há prazer na Dor, esta não se encaixa puramente no contexto psiquiátrico do masoquismo, mas em uma configuração divina natural e sobrenatural, como o próprio Bloy explica no seguinte apotegma: ñTudo em nós é idêntico a Jesus Cristo a quem somos natural e sobrenaturalmente configurados. Portanto, quando recusamos um sofrimento, adulteramos, o quanto houver em nós, nossa própria essênciaò (BLOY, 1902, p. 30). ${ }^{52}$ Por isso, não surpreende sua observação a respeitodos peregrinos de Lourdes: Bloy perguntava-se ironicamente se haveria ñ̃é ] um cristão bem de saúde que vai a Lourdes para obter o benefício da doença [e] um outro cristão rico, curado em Lourdes, pelo mais indubitável dos milagres, e que retorna para distribuir todo seu bem aos pobresò(BLOY, 1902, p. 120-121)..$^{53}$

A interpretação sacrificial cristã de Bloyé contudo, segundo Christian Berg (BERG, 2008, p.46), menos presente ou até ausente dos Evangelhos. Ele parece corresponder a uma visão de mundo em que a corrupção e os vícios imperam, observação feita em Lô̂Ame de Napoléon a respeito de ñuma Europa muito doente e condenada pelos mais sábios doutosơ ${ }^{54}$, o que por sua vez remete à simplicidade da mensagem da Virgem da Salette, duramente descrita por Bloy a ponto de recorrer à imagem pagã da Medusa:

O que eu preciso é a Imaculada Conceição coroada de espinhos, Minha Senhora da Salette, a Imaculada Conceição estigmatizada, sangrando infinitamente e pálida, e desolada, e terrível, dentre suas lágrimas e correntes, em suas sombriasvestimentas de ñDominadora das nações, feita como uma viúva, agachada na solidãoò, a Virgem das Espadas, tal qual a viu

\footnotetext{
${ }^{51}$ ñMais l'Amour écume au seul mot de partage et la jalousie est sa maison. C'est un colimaçon sans patrie, qui se repait, sans convives, dans sa spirale ténébreuse. Il y a des yeux à l'extrémité de ses cornes et, si légèrement qu'on les effleure, il rentre en lui-même pour se dévorer. En même temps, il est ubiquitaire, quant au temps et quant à l'espace, comme le vrai Dieu dont il est la plus effrayante défiguration.ò

52 ñTout en nous estidentique à Jésus-Christ à qui nous sommes naturellement et surnaturellement configurés. Lorsdonc que nous refusons une souffrance, nous adultérons, autant qu'il est en nous, notre propreessence [é ].ò

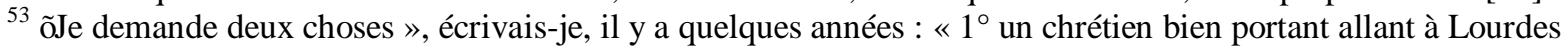
pour y obtenir le bienfait de la maladie ; $2^{\circ}$ un autre chrétien riche, guéri à Lourdes par le plus indubitable miracle, et revenant distribuer tout son bien aux pauvres. Tant que je nôurai pas vu ces deux choses, je croirai que lâEnnemi a voulu profaner, par le Cabotinage, la Médiocrité et lôAvarice, le lieu unique où fut AFFIRMÉ celui de tous les Mystères quâl doit le plus abhorrer : lâmmaculée Conception.ò

${ }^{54}$ BLOY, Léon. L'Âme de Napoléon, p. 56.
} 


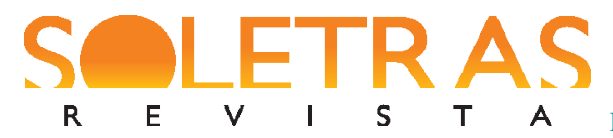

DOSSIÊ ï N. 34 ï 2017.2 ï RÉGIS MIKAIL ABUD FILHO

toda a Idade Média: Medusa de inocência e de dor que transformava em pedras catedrais aqueles que a olhavam chorar (BLOY, 1902, p.120-121). ${ }^{55}$

O dolorismo chega assim a seu paroxismo na figura da Virgem, incompreensível aos ouvidos de seus contemporâneos e seu ñódio à Dorò afastamento máximo da essência cristã aos olhos de Bloy. Por isso, retornemos a Marchenoire sua ânsia por sofrimento, essência sua que ecoa as ideias do próprio Bloy: ñ̃esta Dor] era a seus olhos [é ] o começo como se esta fosse o fimò (BLOY, 1886, p 165). ${ }^{56}$ Todo cristão deveria, a seu ver, aspirar ao martírio: ñEsta velha terra [é ], é rasgada e devastada para a constringira dar a dor à raça humana, a esta ingrata progenitura da dor que não quer sofrerò(BLOY, 1902, p. 23) ${ }^{57}$ Cabe aos santos, escudos da fé católica, garantir a salvação com sua morte e dor. Mas a santidade, para Bloy, parece impossível. Na cena final de La Femme pauvre, Clotilde ' mendiga, devota, só e abandonada ' erra de igreja em igreja, de cemitério em cemitério, ao que o narrador constata que só há uma tristeza: a de não ser santo (BLOY, 1924, p. 388). ${ }^{58}$

Contudo ' e aqui repousa uma outra questão problemática ', os textos católicossobre devoção vitimal parecem indicar que são Deus e Cristo que são reparados, enquanto que o homem torna-se o reparador, conforme observa Christian Berg (BERG, 2008, p. 49). Os sacrifícios serviriam assim, para restauraraordemdivina, como descrito por Bloy:

É por isso que ela iria oferecer suas lágrimas ao Deus das igrejas, sem saber que ela cumpria assim o grande sacrifício, a bem-aventurada e a formidável Oferenda que tem muito mais, sem dúvida, do que o poder de deslocar as constelações, já que o Senhor Jesus não obteve bebida melhor para reconfortá-lo no Suor de Sangue e na Agonia. (BLOY, 1924, p. 32)

Portanto, o dogma católico da Comunhão dos Santos, ño mais incompreendido de todos os dogmas da Igrejaò, é tão importante para Bloy:ñ[os cristãos] saberiam que os sufrágios para os mortos são, de todas as obras da misericórdia, a mais perfeitamente meritória e aquela que vai mais diretamente ao coração do Pai das misericórdiasò(BLOY, in

\footnotetext{
${ }^{55} \tilde{n} C e$ qu'il me faut, c'est l'Immaculée Conception couronnée d'épines, Ma Dame de la Salette, l'Immaculée Conception stigmatisée, infiniment sanglante et pâle, et désolée, et terrible, parmi ses larmes et ses chaînes, dans ses sombres vêtements de óDominatrice des nations, faite comme une veuve, accroupie dans la solitudeô; la Vierge aux Épées, telle que l'a vue tout le Moyen Âge: Méduse d'innocence et de douleur qui changeait en pierres de cathédrales ceux qui la regardaient pleurer.ò

56 «Or, cette Douleur était, à ses yeux, le commencement comme elle était la fin. »

${ }^{57}$ ñCette vieille terre [é ], on la déchire et on la dévaste pour la contraindre à donner le bonheur à la race humaine, à cette ingrate progéniture de la douleur qui ne veut plus souffrir.ò

${ }^{58}$ ñ̃ Il n'y a qu'une tristesse, lui a-t-elle dit, la dernière fois, c'est de n'être pas des SAINTSé ò

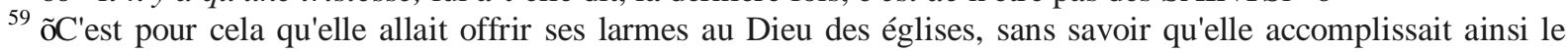
grand sacrifice, la béatifique et la formidable Offrande qui a beaucoup plus, sans doute, que le pouvoir de déplacer les constellations, puisque le Seigneur Jésus n'a pas obtenu de boisson meilleure pour le réconforter dans la Sueur de Sang et dans l'Agonie.ò
} 
BOLLÉRY, 1947, p. 320). ${ }^{60}$ Dessa maneira, todos os homens seriam ñsantos potenciaisò(BLOY, 1917, pp.55-56) ${ }^{61}$, formando ño corpo místico do Cristo de quem todos os fiéis são membros visíveisò (BLOY, 1917, p. 55). ${ }^{62}$

\section{Imaginário medieval, Idade Média imaginada}

O latim medieval dos antifonários fascinou literatos como Remy de Gourmont (autor de Le Latin mystique, de 1892) e o próprio Huysmans por seu caráter renovador, por sua estética que, em pleno final do século XIX, evocava uma certa modernidade de forma e estranheza, devido a seu caráter espiritual em pleno momento de triunfo do laicismo. Já para Bloy, a literatura cristã expressa o sentimento de paroxismo para com o sagrado. Em sua linguagem fortemente rebuscada, causadora de estranheza, coexistem o vulgar e o sublime, o sagrado e o profano. Apontamos acima tais contradições, reveladas pela própria poética bloyana, conforme lemos em Belluaires et porchers: $\tilde{n}[. .$.$] triado palavra por palavra [...]$ dentre as corolas apodrecidas das antigas flores maquiadas de sangueò. (BLOY, 1905, p. 207). ${ }^{63}$ Assim, tais justaposições, expressas em uma linguagem estranha podem ter causado a reticência dos contemporâneos de Bloy em conferir-lhe o devido mérito. A isso se acresce a natureza virulenta de seus escritos e as imprecações contra os católicos de seu tempo, motivo que impediu o reconhecimento de Bloy como escritor católico e como escritor, de maneira geral. Entretanto, alguns nomes da literatura contemporânea, como o recentemente falecido autor Maurice Dantec, contribuem para reviver o interesse pela obra de Bloy.

Bloy manifestou seu talento não apenas na linguagem, mas também nas artes visuais. Assim como a personagem Léopold de La Femme pauvre, foi também iluminador e exímio calígrafo. Seus talentos gráficos transparecem em seus manuscritos de caligrafia firme e elegante, imagem da sua própria écriture. Seus robustos diários, mantidos até seus últimos

\footnotetext{
${ }^{60}$ ñSi les chrétiens connaissaient mieux le plius ignoré et le plus incompris de tous les dogmes de l'Église, c'est-à dire, le dogme de la Communion des Saints, ils sauraient que les suffrages pour les morts sont, de toutes les $\hat{\imath}$ uvres de miséricorde, la plus parfaitement méritoire et celle qui va le plus directement au cî ur du Père des miséricordes.ò

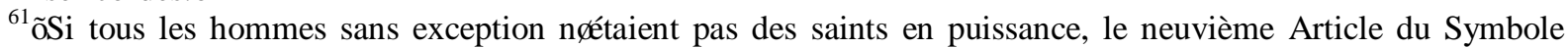
nôurait pas de sens. Il nô aurait pas de Communion des Saints.ò

${ }^{62} \tilde{n}$ Les moins ignorants sont forcés de savoir que telle est la désignation théologique de lấglise, corps mystique du Christ dont tous les fidèles sont membres visibles.ò

${ }^{63} \tilde{n}$ Le sublime latin du Moyen Âge dont les cuistres ont horreur, fut recueilli à tâtons par des peuples agenouillés dans le crépuscule et trié mot à mot, de leurs mains tremblantes, parmi les corolles pourries des anciennes fleurs maquillées de sang.ò̀ (BLOY, Léon. Belluaires et porchers. Paris: Stock, 1905, p. 207).
} 
dias, estão registrados em 25 agendas, dos quais os mais conhecidos portam os títulos sugestivos como Le Pèlerin de lâabsolu (1914)e Le Mendiant ingrat (1898).

Para Bloy, a arte não poderia ser separada da expressão de sua fé. Sua conversão ao catolicismo, em grande parte atribuída ao abade Tardif de Moidrey, ocorreu em 1877. Filho de um pai maçom (ordem que ele execrava) e de uma mãe ardentemente católica (da qual podemos encontrar certos traços em certos personagens femininos embrenhados por uma nostalgia da fé medieval), Bloy se muda em 1864 de sua Dordonha natal para Paris, cidade que ele não cessará de detrair, sem que, no entanto, consiga imaginar-se em outro lugar. Sonhando ser pintor, inscreve-se na Escola de Belas-Artes.

Seus ideais artísticos não poderiam estar mais afastados, portanto, do trabalho esporádico que lhe ajudava a ganhar alguns trocados, ainda que por meio de uma expressão plástica que ele odiava: as imagens pias (images de piété) das editoras católicas Bouasse et Mame. As contradições e os contratempos sempre foram parte, muitas vezes ironicamente, de sua vida. Tratava-se da produção de cartõezinhos e lembrancinhas para os ñcatólicos de bibelôò que ele tanto desprezava. Bloy cunhou o termo art sulpicien em La Femme pauvre para referir-se a uma arte simétrica, bem-comportada e de cores leves e traços simplórios, em azul bebê e o cor-de-rosa, como se via na igreja Saint Sulpice, tão distantes da tradição pictórica medieval. A busca da beleza em Bloy diverge radicalmente daquela pregada pelos decadentistas, embora, conforme vimos, seu gosto pela construção de imagens possa evoque de certa maneira essa escola. Bloy recorre a procedimentos estilísticos que o aproximam da estética e da temática naturalistas, como a representação de camadas pobres, a representação dos falares dessas pessoas e a atenção dada ao detalhe visual e sensorial através da escolha palavras. Nesse mundo dos bas-fonds operários, intercalam-se latinismos, termos raros, científicos etambém expressões do vulgo. O que difere é o intuito da beleza, que por si só nada tem de valor. O verbo só se faz belo quando dialoga diretamente com o Verbo: ñUma sociedade onde se chegou ao ponto de acreditar que o Belo é uma coisa obcena é evidentemente uma sociedade formada por Satã, com uma atenção evangélica e uma experiência terrívelò.(BLOY, 2005, p. 19). ${ }^{64}$

A Arte não é na concepção bloyana um fim, contrariamente aos anseios de vários contemporâneos seus, mas um simples meio de manifestar o simbolismo universal, os revezes

\footnotetext{
${ }^{64}$ ñUne société où on en est à croire que le Beau est une chose obscène est évidemment une sociéte formée par Satan, avec une attention évangélique et une expérience effroyable.ò
} 
e as fortunas da manifestação divina. Em La Femme pauvre, a beleza de um ícone dourado é descrita com detalhes para revelar um dos despertares de Clotilde, mulher pobre e ignorante, para a fé. Quando Bloy recorre à ekphrasis e se serve de descrições ricas, mais ou menos à maneira naturalista, escola cujo materialismo ele afirmava desprezar tanto quanto os floreios do decadentismo, tais descrições tem um propósito claro, explicitado pelo próprio narrador de La Femme pauvre:

A literatura e a arte não haviam estado para nada nesta escalada. Ah! Não, por exemplo. Léopold não era da escola dos Raros que descobrem de repente o catolicismo em um vitral ou em um neuma do cantochão, e que vão, como Folantin, ñdocumentar-seò na Trappe sobre a estética da prece e o garbo da renúncia. Ele não dizia, à maneira desse imbecil, que um serviço fúnebre tem mais grandiosidade do que uma missa nupcial, persuadido até o mais íntimo de sua razão, que todas as formas da Liturgia são igualmente santas e assustadoras.(BLOY, 1924, p.276)

Ridicularizado pelo narrador como misantropo tradicionalista, o personagem Folantin deLa Femme pauvre alude claramente a J.-K. Huysmans e ao protagonista homônimo da novela À vau l'eau, escrita por Huysmans 1882. Folantin parece compreender vários características do próprio Huysmans: longas deambulações por Paris, refeições decepcionantes, impossibilidade de relação conjugal, agruras em relação à vida moderna e ao tédio existencial. Essa longa novela antecede à publicação de À rebours (1884) e antecipa, sob muitos aspectos, o rompimento de Huysmans com o naturalismo. Neste período, Bloy e Huysmans ainda mantinham relações amistosas, unidos pelo desprezo ao mundo moderno, ao materialismo, às abjeções de sua época e ao encantamento que ambos compartilhavam pela Idade Média.

Seria errôneo aproximar Bloy de um desejo de reproduzir totalmente a arte e a literatura medievais, embora a Idade Média ocupe de fato uma posição central em seu pensamento religioso e expressão artística. A expressão desses tempos idealizados e irrecuperáveis coexistem na escrita bloyana, sem, no entanto, cair naquilo que poderia se identificar como preciosismo da parte de Huysmans, detratado por Bloy em Les Dernières Colonnes de l'Église. O léxico da podridão e dos excrementos, conforme já mencionamos,é assim associado à salvação e ao fim dos tempos, em imagens relativamente consoantes à

\footnotetext{
${ }^{65}$ ñLa littérature et l'art n'avaient été pour rien dans cette escalade. Ah ! non, par exemple. Léopold n'était pas de l'école des Rares qui découvrent tout à coup le catholicisme dans un vitrail ou dans un neume du plain-chant, et qui vont, comme Folantin, se 'documenter' à la Trappe sur l'esthétique de la prière et le galbe du renoncement. Il ne disait pas, à l'instar de cet imbécile, qu'un service funèbre a plus de grandeur qu'une messe nuptiale, persuadé, jusqu'au plus intime de sa raison, que toutes les formes de la Liturgie sont également saintes et redoutables.ò
} 
escatologia medieval. Curiosa a aproximação de um âmbito terreno ao divino, pois o Fim, para Bloy é indecidível, indecifrável.

Para exemplificar a (des)construção da narrativa de ficção em Léon Bloy, suas relações com o antirromance e com a espiritualidade profética medieval, não poderíamos deixar de citar o final de La Femme pauvre, momento no qual a expressão máxima da fé de Bloy no poder redentor e fulminante do Espírito Santo é representada de maneira inovadora.

Morreram Lazare, filho de Léopold e Clotilde, assim como Marchenoir, amigo do casal. Em um cemitério, Léopold evoca aproximadamente de memória uma história deixada por Marchenoir sobre um peregrino, ñcomo houve alguns na Idade Médiaò. (Trata-se na verdade de um poema inacabado do próprio Bloy). A narrativa diegética é interrompida e o penúltimo capítulo retoma ipsis litteris uma passagem das Revelações celestes de Santa Brígida da Suécia, registradas em 1455, em latim e sem tradução (livro IV, cap.7). Trata-se de uma visão rica em evocações gráficas poderosas, sensorialmente sugestivas e violentas, de fato infernais, acerca de uma alma vagando em um lugar obscuro ao se deparar com um grande fogaréu. Os sentidos descontrolam-se terrivelmente, um fedor nefasto impera. Ouve-se então a alma gritar por cinco vezes ñVaeò. No início do capítulo seguinte, uma data: 25 de maio de 1887. Exatamente o dia do trágico Incêndio do Bazar de la Charité, iniciativa privada burguesa para arrecadação de fundos destinados à caridade que, por culpa de um problema no cinematógrafo, causou um incêndio incontrolável de proporções devastadoras. Léopold saiu de casa e Clotilde é atravessada por estranhos pressentimentos intercalados por momentos de paz divina. Toma então conhecimento da terrível tragédia e da morte de Léopold. Alguém alegou ter visto no incêndio um homem semelhante a "um bom pirata ou a um demônio", a queimar imóvel, de ñoraços cruzadosò e impassível, após ter entrado na sala em chamas ñtentando salvar da Justiça Divina um número inacreditável de imbecisò ${ }^{66}$ Bloy enxergava nesse acontecimento a manifestação divina através do Espírito Santo em seu fogo purificador, conforme escreve em seu diário: ño incêndio da Opéra-Comique, transposto em delírio de amor divino na alma de Clotilde!ò(BLOY, in PETIT, 1972, p. 430) ${ }^{67}$

Seria o episódio acima a incarnação romanesca dos mistérios da Trindade? O Espírito Santo, ao lado do Cristo e de Deus-Pai, parece orientar-se por atos misteriosos, em sua essência dificilmente definível, inserida no simbolismo universal dos eventos a manifestação

\footnotetext{
${ }^{66}$ BLOY, Léon. La Femme pauvre, p.384.

${ }^{67}$ BLOY, Léon. Journal (27 de fevereiro de 1897): "L'incendie de l'Opéra-Comique, transposé en délire d'amour divin dans l'âme de Clotilde.
} 
da Arte, da Literatura e principalmente da palavra; uma palavra problemática, que nos assola, choca ou deleita, emudecedora.

Principalmente em La Femme pauvreas digressões e metalepses aparecem como herança da tradição romanesca do século XVIII, mas também do sombrio herói byroniano e das narrativas de Barbey d'Aurevilly. A força e a coragem de Marchenoir e Léopold chegam a ser inclusive exageradas e inverossímeis em certos momentos. Tais modelos não visam, portanto, a criar nem a reproduzir um realismo palpável e verossímil, mas a representar o que é deliberadamente hiperbólico, fruto de uma fé igualmente desmedida e de uma imaginação estirada entre as correspondências da terra e do céu, do humano e do divino. ${ }^{68} \mathrm{~A}$ filiação à tradição antirromanesca e o gosto por digressões marcam a presença, mais comentada do que representada, do sobrenatural.Assim como na narrativa de Marchenoir sobre o vegetariano em La Femme pauvre, o exemplum medieval recorrente nas narrativas hagiográficas encontra-se com a técnica das narrativas encaixadas da ficção romanesca. Talvez em uma época que oscilasse entre o naturalismo e o decadentismo, Bloy estivesse deslocado por suas contradições pessoais e de sua fé, motivo pelo qual talvez tenha custado' e ainda custe ' a ser compreendido.

Seria tarefa demasiado longa prosseguir com um percurso da vida e da obra de Léon Bloy, das quais tentou-se aqui traçar um caminho coerente. Situando-o e confrontando-o a seu tempo e ao nosso, procuramos relembrar este autor que por muito tempo foi talvez mais deliberadamente ignorado do que propriamente esquecido, mas que vem ganhando cada vez mais espaço nos meios literários franceses, embora permaneça amplamente desconhecido no Brasil.Aos poucos, o silêncio a seu respeito (no qual Bloy via certamente um injusto complô de seus inimigos), vem quebrando-se.

A um ano antes de morrer, Bloy escrevia em seu diário Au seuil de l'Apocalypse, que ele próprio levara para impressão: ñEu espero os Cossacos e o Espírito Santoò ${ }^{69}$ (BLOY, 1916, p. 351). É um dos mais conhecidos aforismos seus e um dos mais prostituídos por artistas que ele desaprovaria e por movimentos nacionalistas da rompante extrema-direita europeia, os quais ele não hesitaria escarnecer.

\footnotetext{
${ }^{68}$ Quanto aos personagens muitas vezes representados com traços inverossímeis, mais próximos de um romanesco exagerado (semelhanças a Byron e Barbey podem ser apontadas), como no caso de Léopold e Marchenoir, bem como Véronique, cujo terrível sacrifício remete imediatamente ao de Fantine dos Miseráveis.

${ }^{69}$ ñôattends les Cosaques et le Saint-Espritò
} 


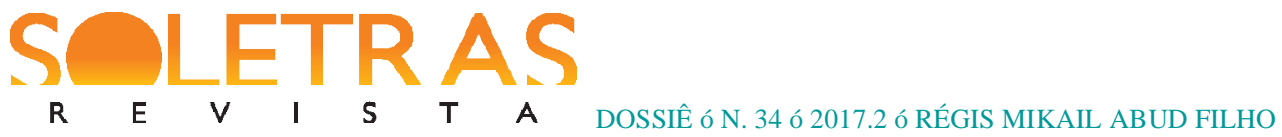

\section{Referências}

BERG, Christian. Abjections de Bloy. In: Silences fin-de-siècle : hommage à Jean de Palacio: actes du colloque international, Paris, la Sorbonne, 20-21 mai 2005, organisé par le Centre de recherche sur la littérature française du XIXe siècle de lốniversité Paris-Sorbonne; sobdireção de André Guyaux. Paris: PUPS, 2008.

. Huysmans hagiographe. In: Cahiers de l'Association internationale des études francaises, $2008, \mathrm{n}^{\circ} 60$, pp. 329-341.

BLANC-DE-SAINT-BONNET, Antoine. De la douleur. Grenoble : Jérome Million, 2008.

BLOY, Léon.Propos dôın entrepreneur de démolitions. Paris: Tresse Éditeurs, 1884.

Le Désespéré. Paris: A. Soirat, 1886.

Le vieux de la montagne; pour faire suite au Mendiant ingrat, à Mon journal, à Quatre ans de captivité a Cochons-sur-Marne et à l'Invendable; 1907-1910. Préf. par André Dupont", 1892.

Exégése des lieux communs. Paris: Mercure de France, 1902.

Les Dernières colonnes de lố́glise. Paris: Mercure de France, 1903.

.Belluaires et porchers. Paris: Stock, 1905.

Le Salut par les Juifs. Paris: Joseph Victorien et Cie., 1906.

- Le Symbolisme de lôApparition, Celle qui pleure, Introduction à la Vie de Mélanie écrite par elle-même en 1900, Vie de Mélanie, écrite par elle-même. Paris: Mercure de France, 1912.

Au seuil de lôApocalypse : pour faire suite au Mendiant ingrat, à Mon journal, à Quatre ans de captivité à Cochons-sur-Marne, à l'Invendable, au Vieux de la Montagne et au Pèlerin de l'absolu, 1913-1915. Paris : Mercure de France, 1916.

. Méditations dôın solitaire en 1916. Paris : Mercure de France, 1917.

. Dans les ténèbres, í uvres, IX. Paris: Mercure de France, 1918.

La Femme pauvre. Paris: Éd. Crès, 1924.

. L'Âme de Napoléon. Paris: Mercure de France, 1930.

. Le Pèlerin de l'Absolu.í uvres. Paris: Mercure de France, 1964.

. Méditations d'un solitaire. Paris : Mercure de France, 1969.

. Mon journal, ed. estabelecida, anotada e apresentada por Pierre Glaudes. Paris :

Robert Laffont, 1999.

SOLETRAS ï Revista do Programa de Pós-Graduação em Letras e Linguística ï PPLIN

Faculdade de Formação de Professores da UERJ

Número 34 (jul.-dez. 2017) - ISSN: 2316-8838

DOI: 
Le Vieux de la montagne. 1907-1910, col. ñBouquinsò, 1999, vol. II. (a)

. Le Pal, numéros 1 a 5, Éditions Obsidiane, 2002.

. Je m'accuse. Jaignes: La Chasse au Snark, 2003.

. Journal Inédit III (1903-1907). Lausanne : Lô̂Âge dâHomme, 2007.

.Le Sang du pauvre. Rennes: La Part Commune, 2009.

. Le siècle de charognes. Paris: Fata Morgana, 2015.

. Aquela que chora. E outros textos sobre Nossa Senhora da Salette, trad. de Roberto

Malet, Ecclesiae, 2016.

BOLLERY, Joseph. Leon Bloy (1) Origines, jeunesseet formation (1846-1882). Paris: Albin Michel, 1947.

CERTEAU, Michel de.La Fable mystique, I, XVIe -XVIIe siècles. Paris: Gallimard, 1982.

FARIA, Octávio de. Léon Bloy. Rio de Janeiro: Record Editora, 1968.

FONTENAY, Élisabeth. Le Silence des bêtes. Paris : Fayard, 1998.

GLAUDES, Pierre. Le tourment de lôrrévocable. (Lecture du Désespéré de Léon Bloy),pp. 34-51, Bulletin de la Société des Études bloyennes, ns 3-4, novembre 1988 janvier 1989.

2006.

Lã uvre romanesque de Léon Bloy. Toulouse: PELH, literature et herméneutique,

GOURMONT, Remy de.Livre de Masques. Houilles: Éditions Manucius, 2007.

GRIFFITHS, Richard. Quelqu'un qui ne sentait pas bon fit son entrée..., Léon Bloy, sous la direction de Michel Arveiller et Pierre Glaudes. Paris: L'Herne, colt. Cahiers de l'Herne, 1988.

GUYOT, Gaëlle. Latin et latinité dans l' î uvre de Léon Bloy. Paris: Honoré Champion, 2003.

Le Saint Siège. Disponível em : <https://w2.vatican.va/content/francesco/fr/homilies/2013/ documents/papafrancesco_20130314_omelia-cardinali.html>. Acesso em : 20 jul. 2017.

[vídeo] Le Pèlerin de l'Absolu. Disponível em <https://youtu.be/LeotBROo6vk>. Acesso em: 3 abr. 2016.

MAISTRE, Joseph de. Í uvres, suivies dôn Dictionnaire Joseph de Maistre, édition établie par Pierre Glaudes. Paris : Robert Laffont, 2007.

PARISSE, Lydie. Mystique et littérature: lôutre de Léon Bloy. Caen: Minard, 2006.

PERRONE-MOISÉS, Leila. A Falência da crítica Ï Um caso limite: Lautréamont. São Paulo: Perspectiva, 1973. 


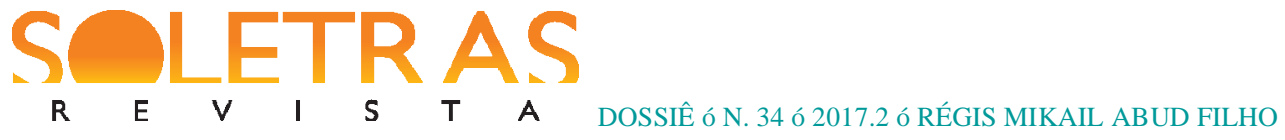

PRZYBOS, Julia. Les Aventures du corps masculin. Paris : José Corti, 2012

\title{
Léon Bloy, against his time
}

\begin{abstract}
Léon Bloy, a polemic French writer of the end of the XIX century and critic of his time, is mostly known by the ferocity of his writings. This article aims to establish a panorama of the life and work of this writer yet insufficiently considered in Brazil. Thus, three fundamental aspects of his work, enrooted in his unique catholic faith, have been chosen: pain, money and art. Such aspects are marked by contradictions such as money, which plays a redemptive and maleficent role. The Bible as well as the mystic and hagiographic writings of the Middle Ages are sources in which Bloy sought inspiration. Eschatology, the mystery of reversibility and the redemptive role of the woman are present in most literary forms under which Bloy wrote, explained here in some examples. His historiographic perspective is based on the "universal symbolism" and in the legacy of authors such as Barbeyd'Aurevilly, Joseph de Maistre, Blanc-de-Saint-Bonnet and Thomas Carlyle. Bloy's literature goes against the grain of the artistic guidelines of his century. It abhorrers openly the bourgeois cupidity, often depicted as ridiculous and satanic. Bloy's writing does not present itself as an end, but instead as a simple means of reaching God.
\end{abstract}

Keywords: Léon Bloy. Literature. Pain. Money. Art.

Recebido em: 01 de setembro de 2017.

Aprovado em: 25 de outubro de 2017. 